Effects of codoping in ZnO-based semimagnetic semiconductor thin films

This article has been downloaded from IOPscience. Please scroll down to see the full text article.

2010 IOP Conf. Ser.: Mater. Sci. Eng. 8012042

(http://iopscience.iop.org/1757-899X/8/1/012042)

View the table of contents for this issue, or go to the journal homepage for more

Download details:

IP Address: 178.93.141.108

The article was downloaded on 27/09/2010 at 17:58

Please note that terms and conditions apply. 


\title{
Effects of codoping in ZnO-based semimagnetic semiconductor thin films
}

\author{
AI Savchuk ${ }^{1}$, VP Makhniy ${ }^{1}$, VI Fediv ${ }^{1}$, GI Kleto ${ }^{1}$, SA Savchuk ${ }^{1}$, A Perrone ${ }^{2}$ and \\ L Cultrera $^{3}$ \\ ${ }^{1}$ Department of Physics of Semiconductors and Nanostructures, Chernivtsi National \\ University, 58012 Chernivtsi, Ukraine \\ ${ }^{2}$ University of Salento, Physaics Departnment and National institute of Nuclear \\ Physics, 73100 Lecce, Italy \\ ${ }^{3}$ National Institute of Nuclear physics, National Laboratory of Frascati, Frascati, Italy
}

Email: a.savchuk@chnu.edu.ua

\begin{abstract}
Single doped $\mathrm{Zn}_{1-\mathrm{x}} \mathrm{Mn}_{\mathrm{x}} \mathrm{O}, \mathrm{Zn}_{1-\mathrm{x}} \mathrm{Fe}_{\mathrm{x}} \mathrm{O}$ and codoped $\mathrm{Zn}_{1-\mathrm{x}-\mathrm{y}} \mathrm{Mn}_{\mathrm{x}} \mathrm{Fe}_{\mathrm{y}} \mathrm{O}, \mathrm{Zn}_{1-\mathrm{x}-\mathrm{y}} \mathrm{Mn}_{\mathrm{x}} \mathrm{Sn}_{\mathrm{y}} \mathrm{O}$, $\mathrm{Zn}_{1-x-y} \mathrm{Mn}_{\mathrm{x}} \mathrm{Li}_{\mathrm{y}} \mathrm{O}, \mathrm{Zn}_{1-\mathrm{x}-\mathrm{y}} \mathrm{Fe}_{\mathrm{x}} \mathrm{Al} \mathrm{y} \mathrm{O}$ thin films were grown on sapphire and glass substrate by pulsed laser deposition and RF sputtering techniques. No secondary phases was detected from $\mathrm{XRD}$ analysis. Among the studied oxide films single doped with $\mathrm{Fe}$ and codoped with $(\mathrm{Mn}, \mathrm{Fe})$ and $(\mathrm{Fe}, \mathrm{Al})$ exhibit n-type conductivity and room temperature ferromagnetic behaviour. For the films codoped with (Mn, Sn) formation of clusters including nanowire-like structures was shown from AFM analysis. Optical and magnetooptical studies suggest of $\mathrm{Mn}, \mathrm{Fe}, \mathrm{Sn}$ and $\mathrm{Li}$ substitution for $\mathrm{Zn}^{2+}$ ions in $\mathrm{ZnO}$ lattice.
\end{abstract}

\section{Introduction}

In recent years semimagnetic semiconductor (SMS) or diluted magnetic semiconductor oxides are subjects of considerable attention because of their potential applications in optoelectronic and spintronic devices [1-3]. In particular, a key point to realize spintronic devices is to fabricate material with ferromagnetic ordering at room temperature. Among different SMS materials, ZnO-based systems doped with transition metals (TM) belong to the most attractive, since there is possibility to control independently the concentration of the charge and spin of the carriers. However, the experimental confirmation of ferromagnetism in ZnO-based SMS is controversial, and the mechanisms of such an ordering are unclear [4-8]. One of the possible explanations of the ferromagnetism in these materials is to reveal defects which increase concentration of free carriers. Such delocalized carriers can hybridize with the localized spins of magnetic impurity atoms and provide exchange coupling between d-spins localized on magnetic atoms [4]. Another possible pathway for inducing ferromagnetism was pointed out by consideration of codoping, i.e. the simultaneous presence of two kinds of defects [7]. It was considered the role of the $\mathrm{Cu}$ ions in codoped $\mathrm{Zn}(\mathrm{Co}, \mathrm{Cu}) \mathrm{O}$ which act as superexchange mediators. There is suggestion that the role of $\mathrm{Cu}$ ions is analogous to that played by the free electron in the development of RKKY interaction. The interesting 
point should be mentioned which consists in a concept that the presence of TM is not necessary for providing of the ferromagnetic properties of $\mathrm{ZnO}$-based oxides [8]. Even pure $\mathrm{ZnO}$ can be ferromagnetic, critical is the low grain size, and not the doping with magnetic atoms as it was originally supposed.

In our previous works $[9,10]$, we carried out studies of the $\mathrm{Mn}$ single doped $\mathrm{ZnO}$ bulk crystals and thin films. In this work, in order to study effects of codoping we focus main attention on growth and characterization of single doped $\mathrm{Zn}_{1-\mathrm{x}} \mathrm{Mn}_{\mathrm{x}} \mathrm{O}, \mathrm{Zn}_{1-\mathrm{x}} \mathrm{Fe}_{\mathrm{x}} \mathrm{O}$ and codoped $\mathrm{Zn}_{1-\mathrm{x}-\mathrm{y}} \mathrm{Mn}_{\mathrm{x}} \mathrm{Fe}_{\mathrm{y}} \mathrm{O}, \mathrm{Zn}_{1-\mathrm{x}-\mathrm{y}} \mathrm{Mn}_{\mathrm{x}} \mathrm{Sn}_{\mathrm{y}} \mathrm{O}$, $\mathrm{Zn}_{1-\mathrm{x}-\mathrm{y}} \mathrm{Mn}_{\mathrm{x}} \mathrm{Li}_{\mathrm{y}} \mathrm{O}, \mathrm{Zn}_{1-\mathrm{x}-\mathrm{y}} \mathrm{Fe}_{\mathrm{x}} \mathrm{Al}_{\mathrm{y}} \mathrm{O}$ thin films.

\section{Experimental}

Two different techniques were used for growth of $\mathrm{ZnO}$-based oxide thin films. The single doped $\mathrm{Zn}_{1-\mathrm{x}} \mathrm{Mn}_{\mathrm{x}} \mathrm{O}$ and $\mathrm{Zn}_{1-\mathrm{x}} \mathrm{Fe}_{\mathrm{x}} \mathrm{O}$ thin films with composition in range of $0 \leq \mathrm{x} \leq 0.1$ were deposited by pulsed laser deposition (PLD) technique. In PLD set-up an ultrahigh vacuum chamber with a base pressure of $10^{-7} \mathrm{~Pa}$ and $\mathrm{XeCl}$ excimer laser $(\lambda=308 \mathrm{~nm}, \tau=30 \mathrm{~ns})$ were applied. Laser was operated at a repetition rate of $10 \mathrm{~Hz}$, and laser fluence was about $5.5 \mathrm{~J} / \mathrm{cm}^{2}$.

Codoped $\mathrm{Zn}_{1-\mathrm{x}-\mathrm{y}} \mathrm{Mn}_{\mathrm{x}} \mathrm{Fe}_{\mathrm{y}} \mathrm{O}, \mathrm{Zn}_{1-\mathrm{x}-\mathrm{y}} \mathrm{Mn}_{\mathrm{x}} \mathrm{Sn}_{\mathrm{y}} \mathrm{O}, \mathrm{Zn}_{1-\mathrm{x}-\mathrm{y}} \mathrm{Mn}_{\mathrm{x}} \mathrm{Li}_{\mathrm{y}} \mathrm{O}, \mathrm{Zn}_{1-\mathrm{x}-\mathrm{y}} \mathrm{Fe}_{\mathrm{x}} \mathrm{Al}_{\mathrm{y}} \mathrm{O}$ were grown by RFdiode sputtering technique with planar cathode and $1.76 \mathrm{MHz}$ power source in argon-oxygen mixture.

Targets for both techniques were prepared by pressing with using of $\mathrm{ZnO}, \mathrm{Mn}_{3} \mathrm{O}_{4}, \mathrm{Fe}_{3} \mathrm{O}_{4}, \mathrm{SnO}_{2}$, $\mathrm{Li}_{2} \mathrm{O}$ pure powders as initial components. Mainly glass and sapphire were used as substrates. The substrate temperature was varied between 20 and $350^{\circ} \mathrm{C}$.

$\mathrm{X}$-ray diffraction (XRD) technique with $\mathrm{Cu} \mathrm{K}+$ radiation was used to characterize the crystal structure of the films. Atomic force microscopy (AFM) [Nanotec Cervantes AFM] was used to evaluate the surface morphology of the films. Optical transmission and absorption spectra were measured in range of (0.2-25) $\mu \mathrm{m}$ at temperatures of (4.2-300) K. Magneto-optical Faraday effect was measured in range of (400-700) $\mathrm{nmm}$ in magnetic field up to $5 \mathrm{~T}$.

\section{Results and discussion}

Figure 1 shows XRD patterns of the as-prepared $\mathrm{Zn}_{1-\mathrm{x}-\mathrm{y}} \mathrm{Mn}_{\mathrm{x}} \mathrm{Fe} \mathrm{y}_{\mathrm{y}} \mathrm{O}$ and $\mathrm{Zn}_{1-\mathrm{x}-\mathrm{y}} \mathrm{Mn}_{\mathrm{x}} \mathrm{Sn}_{\mathrm{y}} \mathrm{O}$ thin films on sapphire substrates. It can be seen that the samples possess hexagonal wurtzite structure. The only difference was observed in the relative intensity of [002] peak to [004] peak and in width of diffraction lines for two different codoped films. No secondary phases can be detected from XRD analysis of the studied oxide films.

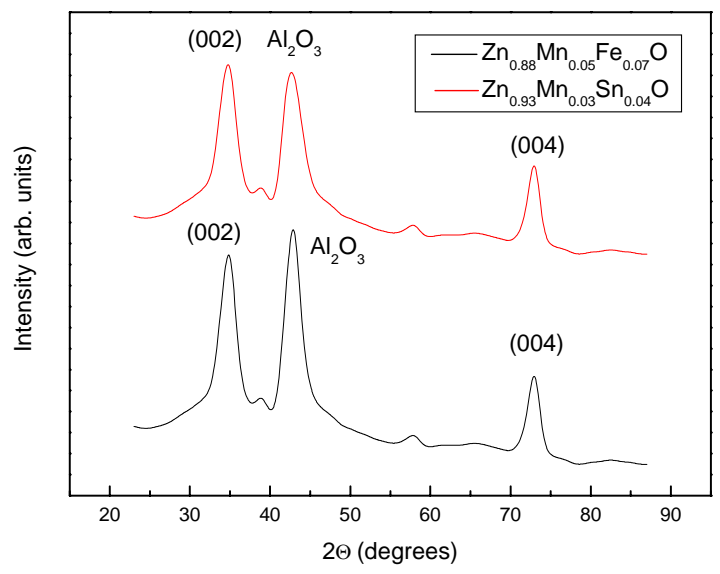

Figure 1. XRD patterns of $\mathrm{Zn}_{0.88} \mathrm{Mn}_{0.05} \mathrm{Fe}_{0.07} \mathrm{O}$ and $\mathrm{Zn}_{0.86} \mathrm{Mn}_{0.1} \mathrm{Sn}_{0.04} \mathrm{O}$ thin films on sapphire substrate. 
To determine the surface morphology of the codoped films, AFM analysis was performed for several samples. AFM image corresponding to $\mathrm{Zn}_{0.85} \mathrm{Li}_{0.09} \mathrm{Mn}_{0.06} \mathrm{O}$ film deposited by $\mathrm{RF}$ sputtering on glass substrate is shown in Figure 2a. This image indicates that the surface roughness of the $\mathrm{Zn}_{0.85} \mathrm{Li}_{0.09} \mathrm{Mn}_{0.06} \mathrm{O}$ film is very high with a root mean square roughness (Rms) of $4.3 \mathrm{~nm}$. In contrast, for codoped $\mathrm{Zn}_{0.93} \mathrm{Mn}_{0.03} \mathrm{Sn}_{0.04} \mathrm{O}$ film AFM image shown in Figure $2 \mathrm{~b}$ suggests of more complicated surface morphology. There is clear evidence for the formation of elongated clusters which in turn consist of nanowires. The estimated length of nanowires is about 3-4 $\mu \mathrm{m}$, and average diameter is about $10 \mathrm{~nm}$. The observed nanostructures are oriented mainly along the surface plane.

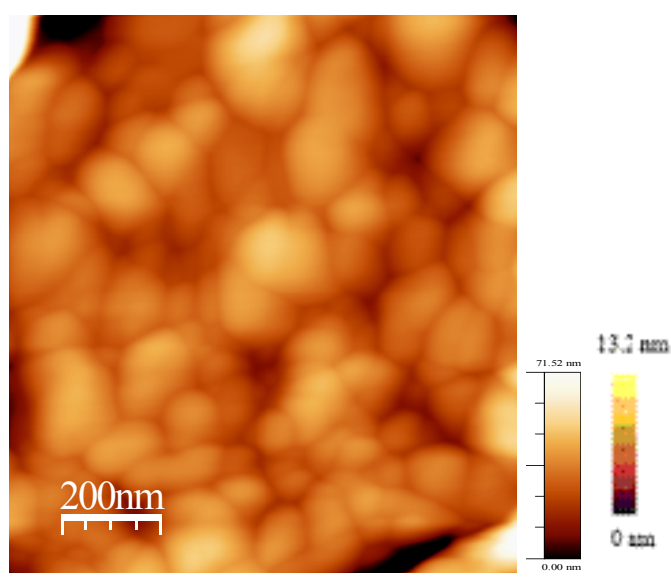

a

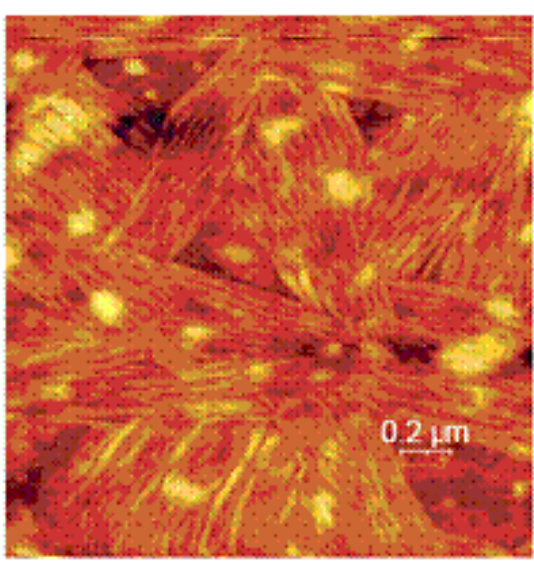

b

Figure 2. AFM micrographs (topography in dynamic mode) of $\mathrm{Zn}_{0.85} \mathrm{Li}_{0.09} \mathrm{Mn}_{0.06} \mathrm{O}$ (a) and $\mathrm{Zn}_{0.93} \mathrm{Mn}_{0.03} \mathrm{Sn}_{0.04} \mathrm{O}$ (b) thin films on glass substrate.

Electrical and magnetic characteristics of the studied single doped and codoped films are summarized in Table 1. Undoped $\mathrm{ZnO}$ films as a rule exhibit n-type conductivity which can be explained by inner defects. Among the codoped materials we would like to focus on $\mathrm{Zn}_{0.88} \mathrm{Mn}_{0.05} \mathrm{Fe}_{0.07} \mathrm{O}$ and $\mathrm{Zn}_{0.85} \mathrm{Fe}_{0.1} \mathrm{Al}_{0.05} \mathrm{O}$ thin films which exhibit p-type conductivity and ferromagnetic behavior. On the other hand, the codoped $\mathrm{Zn}_{0.86} \mathrm{Mn}_{0.1} \mathrm{Sn}_{0.04} \mathrm{O}$ and $\mathrm{Zn}_{0.85} \mathrm{Fe}_{0.1} \mathrm{Al}_{0.05} \mathrm{O}$ thin films are characterized n-type conductivity and paramagnetic behavior. The presence of room temperature magnetism in $\mathrm{Zn}_{0.9} \mathrm{Fe}_{0.1} \mathrm{O}$ and the first couple of codoped materials can be associated with influence of Fe dopant.

Table 1. Electrical and magnetic characteristics of oxide thin films

\begin{tabular}{lccc}
\hline $\begin{array}{c}\text { Film } \\
\text { compositions }\end{array}$ & $\begin{array}{c}\text { Type of } \\
\text { conductivity }\end{array}$ & $\begin{array}{c}\text { Conductivity } \\
(\Omega \mathrm{cm})^{-1}\end{array}$ & Magnetic state \\
\hline $\mathrm{ZnO}$ & $\mathrm{n}$ & $10^{-7}$ & diamagnetic \\
$\mathrm{Zn}_{0,97} \mathrm{Mn}_{0,03} \mathrm{O}$ & $\mathrm{n}$ & $10^{-6}$ & paramagnetic \\
$\mathrm{Zn}_{0,9} \mathrm{Fe}_{0,1} \mathrm{O}$ & $\mathrm{p}$ & $2 \times 10^{-7}$ & ferromagnetic \\
$\mathrm{Zn}_{0,86} \mathrm{Mn}_{0,1} \mathrm{Sn}_{0,04} \mathrm{O}$ & $\mathrm{n}$ & $1.6 \times 10^{-4}$ & paramagnetic \\
$\mathrm{Zn}_{0,88} \mathrm{Mn}_{0,05} \mathrm{Fe}_{0,07} \mathrm{O}$ & $\mathrm{p}$ & $2 \times 10^{-6}$ & ferromagnetic \\
$\mathrm{Zn}_{0,85} \mathrm{Fe}_{0,1} \mathrm{Al}_{0,05} \mathrm{O}$ & $\mathrm{p}$ & $5.5 \times 10^{-4}$ & ferromagnetic \\
$\mathrm{Zn}_{0,85} \mathrm{Mn}_{0,06} \mathrm{Li}_{0,09} \mathrm{O}$ & $\mathrm{n}$ & $10^{-6}$ & paramagnetic \\
\hline
\end{tabular}

Optical transmission spectra for several samples of the codoped oxide SMS are shown in Figure 3. They have typical form in spectral range near energy band gap. The absorption edge is broadened because of disordering effect for quaternary SMS. In addition, the absorption edge is shifted towards 
the lower wavelength side with the increase of $\mathrm{Mn}, \mathrm{Fe}, \mathrm{Sn}, \mathrm{Al}$ and $\mathrm{Li}$ content. In Figure 4 magnetic field dependence of Faraday rotation is shown demonstrating ferromagnetic behavior for codoped $\mathrm{Zn}_{0,88} \mathrm{Mn}_{0,05} \mathrm{Fe}_{0,07} \mathrm{O}$ film.

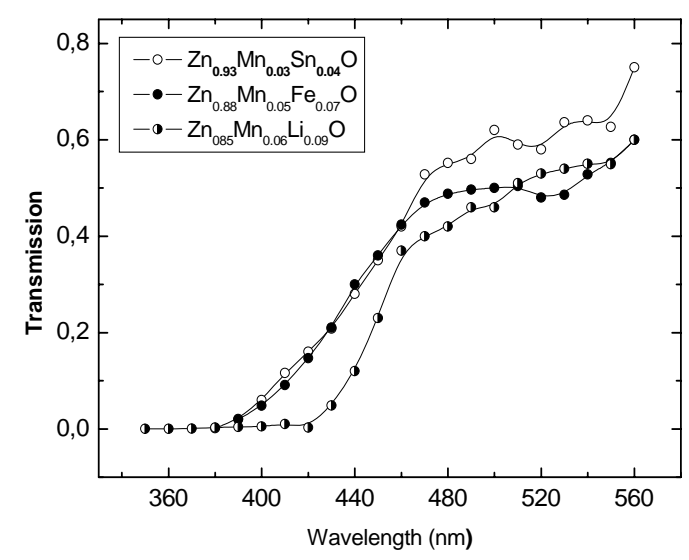

Figure 3. Transmission spectra of codoped oxide SMS thin films.

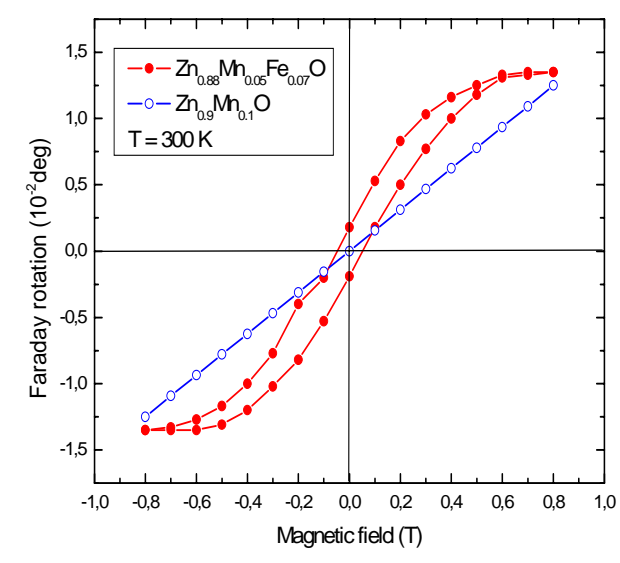

Figure 4. Faraday rotation vs magnetic field for single doped and codoped thin films.

\section{Conclusion}

Thin films of SMS oxides were grown by PLD and RF sputtering techniques. XRD analysis has not revealed secondary phases. AFM images demonstrate different surface morphology depending on growth conditions and film compositions. Optical and magneto-optical spectra are typical for SMS materials. The obtained results confirm possibility to induce ferromagnetism in ZnO-based SMS by codoping.

\section{Acknowledgements}

This research was partially supported by the Ministry of Education and Science of Ukraine. The authors would like to thank Mrs. E. Gomez from Nanotec Electronica S.L. for performing of AFM analysis.

\section{References}

[1] Pearton S J, Abernathy C R, Norton D P, Hebard A F, Park Y D, Boatner L A and Budai J D 2003 Mater. Sci. Engin. R 40 137-68.

[2] Ozgur U, Alivov Ya I, Liu C, Teke A, Reshchikov M A, Dogan S, Avrutin V, Cho S J and Morkoc H 2005 J. of Appl. Phys . 98 041301-103.

[3] Pan F, Song C, Liu X J, Yang Y C and Zeng F 2008 Mater. Sci. Engin. R 62 1-35.

[4] Chang G S, Kurmayev E Z, Boukhvalov D W, Finkelstein L D, Moewes A, Bieber H, Colis S and Dinia A 2009 J.Phys.:Condens.Matter 21056002.

[5] Kittilstved K R, Schwartz D A, Tuan A C, Heald S M, Chambers S A and Gamelin D R 2006 Phys. Rev. Lett. 97037203.

[6] Straumal B B, Mazilkin A A, Protasova S G, Myatiev A A, Straumal P B, Schutz G, Aken P A, Goering E and Baretzky B 2009 Phys.Rev. B 79205206.

[7] Lathiotakis N N, Andiotis A N and Menon M 2008 Phys.Rev. B78 193311.

[8] Sundaresan A and Rao C N R 2009 Nano Today 4 96-106.

[9] Savchuk A I, Gorley P N, Khomyak V V, Ulyanytsky K S, Bilichuk S V, Perrone A and Nikitin P I 2004 Mater.Sci.Engin. B 109 196-9.

[10] Savchuk A I, Fediv V I, Savchuk S A and Perrone A 2005 Superlattices and Microstructures 38 421-7. 